\title{
Anti-leptospiral agglutinins in marmosets (Saguinus oedipus and Saguinus leucopus) from illegal trade
}

\section{Aglutininas anti-leptospira en monos tití (Saguinus oedipus y Saguinus leucopus) de comercio ilegal}

\author{
Viviana Gonzalez-Astudillo, ${ }^{1 *}$ M.Sc, Juliana Peña-Stadlin, ${ }^{2}$ MV, \\ Miryam Astudillo-Hernandez, ${ }^{3}$ M.Sc.
}

\begin{abstract}
${ }^{1}$ University of Queensland, School of Veterinary Science, Gatton QLD, 4343, Australia. ${ }^{2}$ Fundación Zoológica de Cali, Unidad de Bienestar Animal, Cra. 2 Oeste Cll. 14, Cali, Colombia. ${ }^{3}$ Universidad del Valle, Departamento de Microbiología, Av. 1N No. 3N-03, Sede Centenario, Cali, Colombia. *Correspondence: v.gonzalez@uq.edu.au
\end{abstract}

Received: September 2014; Accepted: February 2015.

\begin{abstract}
Objective. Determine the infection status with pathogenic Leptospira of one Saguinus oedipus and nine Saguinus leucopus at the Cali Zoo that had been confiscated in Colombia from illegal trade. Materials and methods. A full physical examination, blood work, urinalysis were conducted in all individuals during the reception health check-up, in addition to running the microagglutination test with a pool of 19 serovars, with a starting dilution of $1: 50$. Results. A high positive titer $(\geq 1: 3200)$ to Leptospira alexanderi serovar manhao in an asymptomatic S. oedipus was detected. All S. leucopus tested negative or less than 1:50. Conclusions. Captive locations have been documented to artificially enhance opportunities to come into contact with contaminated bodily fluids from peridomestic rodents. However, infectious diseases acquired during the illegal transport of wildlife to major metropolitan centers are rarely considered a wildlife conservation or public health threat. Infection with zoonotic pathogens should also be considered an additional threat to endangered wild primates involved in illegal trade, which could hamper reintroduction efforts or other population management procedures for primate species with restricted and fragmented distributions.
\end{abstract}

Key words: Illegal trade, primate, serology, spirochete, zoonosis (Source: MeSH).

\section{RESUMEN}

Objetivo. Determinar el estado de infección con Leptospira patógena en un Saguinus oedipus y nueve Saguinus leucopus en el Zoológico de Cali tras haber sido decomisados de tráfico ilegal en Colombia. Materiales y métodos. Se procedió a realizar un examen físico, cuadro hemático y bioquímica, urianálisis, y adicionalmente se realizó la prueba de microaglutinación con un pool de 19 serovares, en una dilución inicial de $1: 50$. Resultados. Se detectó una respuesta elevada en títulos $(\geq 1: 3200)$ a Leptospira alexanderi serovar manhao en un S. oedipus. Todos los S. leucopus resultaron negativos o 
con títulos menores de 1:50. Conclusiones. Se ha documentado que el cautiverio puede incrementar artificialmente las oportunidades para que los animales en encierros entren en contacto con fluidos corporales contaminados de roedores peridomésticos. Sin embargo, las enfermedades infecciosas adquiridas durante el transporte ilegal de la fauna silvestre a los principales centros metropolitanos son rara vez consideradas amenazas a la conservación de la fauna o para la salud pública. La infección con patógenos zoonóticos se debería también considerar como un riesgo adicional para primates en peligro de extinción involucrados en tráfico ilegal, lo que podría afectar esfuerzos de reintroducción u otras medidas de manejo de poblaciones de primates con distribuciones fragmentadas y restringidas.

Palabras clave: Espiroqueta, primate, serología, tráfico ilegal, zoonosis (Fuente: MeSH).

\section{INTRODUCTION}

Leptospirosis is a bacterial zoonosis primarily linked to the humid and warm climates of tropical regions (1). The etiological agent, Leptospira, is transmitted directly or indirectly to humans when excreted in the urine or other contaminated bodily fluids by reservoirs (mainly peridomestic rodents) (1). Epidemiologically, humans are considered dead-end hosts; however, different studies endeavor to determine the potential role of wild or zoo mammals (primarily nonhuman primates) as reservoirs of infection (1). Leptospira has been identified as an important and widespread pathogen detected in wildlife imported to the U.S. (1); this bacterium is of particular concern due to its capability of infecting several vertebrate genera and zoonotic risk (2). However, few studies have identified pathogens of zoonotic potential in wild animals traded illegally in Colombia. Wild animals are brought into major metropolitan areas in Colombia to be sold illegally as pets and when confiscated by environmental authorities (Environmental Police), they are brought into wildlife rehabilitation facilities, in which the final fate of the animal is to be decided (e.g. re-introduction, euthanasia, zoo collection, etc.). During their transient captivity period, wild animals can acquire infections that would be unlikely to occur in natural conditions. This has been particularly studied in non-human primates due to their generic relatedness to humans. Primates in zoological collections are spatially restricted and are brought into closer contact to maintenance hosts of zoonotic pathogens such as Leptospira spp., (1) when attracted by e.g. odors or feeding material.

Most Neotropical primates, such as callitrichids, are nearly strictly arboreal and disperse their feed; activities that have been suggested to decrease opportunities for Leptospira transmission from grounddwelling rodents (3). However, the role of illegal trade, which has spiked over the

\section{INTRODUCCIÓN}

Leptospirosis es una zoonosis bacteriana principalmente relacionada con climas húmedos y cálidos de las regiones tropicales (1). El agente etiológico, Leptospira, se transmite directa o indirectamente a los humanos cuando se excreta en la orina u otros fluidos corporales contaminados por reservorios (principalmente roedores peridomésticos)(1). Epidemiológicamente, los humanos son considerados hospederos terminales; sin embargo, diferentes estudios pretenden determinar el rol potencial de mamíferos silvestres o de zoológicos (principalmente primates no humanos) como reservorios de infección (1). La Leptospira se puede identificar como un patógeno importante y ampliamente difundido detectado en vida silvestre importada a los EE.UU. (1); este patógeno es de particular preocupación debido a su capacidad de infectar varios géneros de vertebrados y por su riesgo zoonótico. (2). Sin embargo, pocos estudios han identificado patógenos con potencial zoonótico en animales silvestres comercializados ilegalmente en Colombia. Los animales silvestres son introducidos a áreas metropolitanas importantes en Colombia para ser vendidos ilegalmente como mascotas y luego confiscados por las autoridades ambientales (Policía Ambiental), son llevados a instalaciones de rehabilitación de vida silvestre, en donde el destino final del animal se decide (ej. reintroducción, eutanasia, colección de zoológico, etc.). Durante este periodo transitorio en cautiverio, los animales silvestres adquieren infecciones que no ocurrirían en condiciones naturales. Esto se ha estudiado particularmente en primates no humanos debido a su relación genética con los humanos. Los primates en colecciones de zoológico están restringidos en espacio y son llevados a un contacto más cercano con los hospederos de patógenos zoonóticos como la Leptospira spp., (1) cuando son atraídos por ej. olores y restos de comida.

La mayoría de los primates Neotropicales, como los calitrícidos, son estrictamente arbóreos y dispersan los restos de comida; se ha sugerido que estas actividades disminuyen las oportunidades de transmisión de Leptospira de roedores terrestres (3). Sin embargo, el rol del comercio ilegal, que ha incrementado de manera significativa en las últimas décadas (4) y cómo este puede 
last decades (4) and how it may enhance zoonotic pathogen transmission in wildlife in Colombia, a biodiversity hotspot, has not been thoroughly studied. Both Saguinus oedipus and Saguinus leucopus are endemic to Colombia, and are two of the most commonly trafficked primate species.

Both species are placed in conservation categories of concern (critically endangered and endangered, respectively (5)) due to the negative interplay of illegal trade, forest cover loss due to intensive colonization, and restricted geographical distribution. Infectious diseases are not currently considered as a threat to wild populations of this species, nor there have been a reported case of zoonotic pathogen transmission between trafficked animals and humans in Colombia.

\section{MATERIALS AND METHODS}

Study site. Cali Zoo is located in Cali, a major metropolitan center in the southwest of Colombia. Its coordinates are $3.4486^{\circ}$ and $76.5586^{\circ}$ in the northern and western latitude respectively, with an altitude of 1014 $\mathrm{m}$. The local climate is defined as a tropical savanna, with an annual precipitation between 900 to $1.800 \mathrm{~mm}$ and an average temperature of $25^{\circ} \mathrm{C}$ and relative humidity of $\sim 70 \%(6)$.

Study population, sample collection and processing. One adult female $S$. oedipus arrived to the Cali Zoo after being surrendered by his possessor in July 2013 to environmental authorities (Figure 1a). In February 2014 a group of nine S. leucopus arrived to the Cali Zoo after being seized by the Environmental Police (Figure 1b, 1c). All individuals from both species were chemically immobilized using ketamine ( $3 \mathrm{mg} / \mathrm{kg}$ IM) and midazolam $(0.05 \mathrm{mg} /$ $\mathrm{kg}$ IM) in order to receive a health checkup consisting of full physical examination, blood (CBC, biochemistry) and urine testing. Special consideration was made to detect clinical signs that have been associated with zoonotic diseases such as leptospirosis (e.g., such as weight loss, diarrhea, dehydration, anorexia, jaundice and anemia).

Handling and sample collection were performed by a veterinarian with extensive experience in Colombian captive nondomestic fauna. This study complied with the Zoological Foundation of Cali veterinary protocols, which adhere to the legal requirements of zoological collections dictated by the Colombian Association of Zoological Parks and Aquariums ACOPAZOA, the Latin American Association of Zoological Parks and Aquariums - ALPZA, aumentar la transmisión de patógenos zoonóticos en la vida silvestre en Colombia, un "hotspot" de biodiversidad, no ha sido discutido a fondo. Saguinus oedipus y Saguinus leucopus son endémicos de Colombia, y son dos de las especies de primates más comúnmente traficadas.

Ambas especies se encuentran en importantes categorías de conservación (en peligro crítico y en peligro, respectivamente (5)) debido a la interacción negativa entre comercio ilegal, pérdida de cubierta forestal debido a colonización intensiva y distribución geográfica restringida. Las enfermedades infecciosas no se consideran actualmente como una amenaza a las poblaciones silvestre de estas especies, ni se ha reportado un caso de transmisión de patógenos zoonóticos entre animales traficados y humanos en Colombia.

\section{MATERIALES Y MÉTODOS}

Locación de Estudio. El Zoológico está ubicado en Cali, un centro metropolitano importante en el suroeste de Colombia. Sus coordenadas son $3.4486^{\circ}$ y $76.5586^{\circ}$ en latitud norte $y$ oeste respectivamente, con una altitud de $1014 \mathrm{~m}$. El clima local se define como sabana tropical con una precipitación anual entre 900 y $1.800 \mathrm{~mm}$ y una temperatura promedio de $25^{\circ} \mathrm{C}$ y humedad relativa de $\sim 70 \%(6)$.

Población de estudio, recolección y procesamiento de muestras. Una hembra adulta de S. oedipus llegó al Zoológico de Cali luego de ser entregada por su posesor en Julio 2013 a las autoridades ambientales (Figura 1a). En febrero de 2014 un grupo de nueve $S$. seucopus llegó al Zoológico de Cali luego de ser decomisados por la Policía Ambiental (Figura 1b, 1c). Todos los individuos de ambas especies fueron inmovilizados químicamente utilizando ketamina (3 mg/kg IM) y midazolam $(0.05 \mathrm{mg} / \mathrm{kg}$ IM) para recibir un chequeo de salud que consistió en un examen físico completo, pruebas de sangre ( $C B C$, bioquímica) y de orina. Se tomó especial consideración en detectar señales clínicas asociadas con enfermedades zoonóticas como la leptospirosis (por ej. pérdida de peso, diarrea, deshidratación, anorexia, ictericia y anemia).

El manejo y recolección de muestras se llevó a cabo por un veterinario con amplia experiencia en fauna Colombiana no doméstica en cautiverio. El estudio cumplió con los protocolos veterinarios de la Fundación del Zoológico de Cali, los cuales se adhieren a los requerimientos legales de colecciones de zoológico según los dicta la Asociación Colombiana de Parques Zoológicos y Acuarios - ACOPAZOA, la Asociación Latinoamericana de Parques Zoológicos y Acuarios - ALPZA, y el departamento local de 

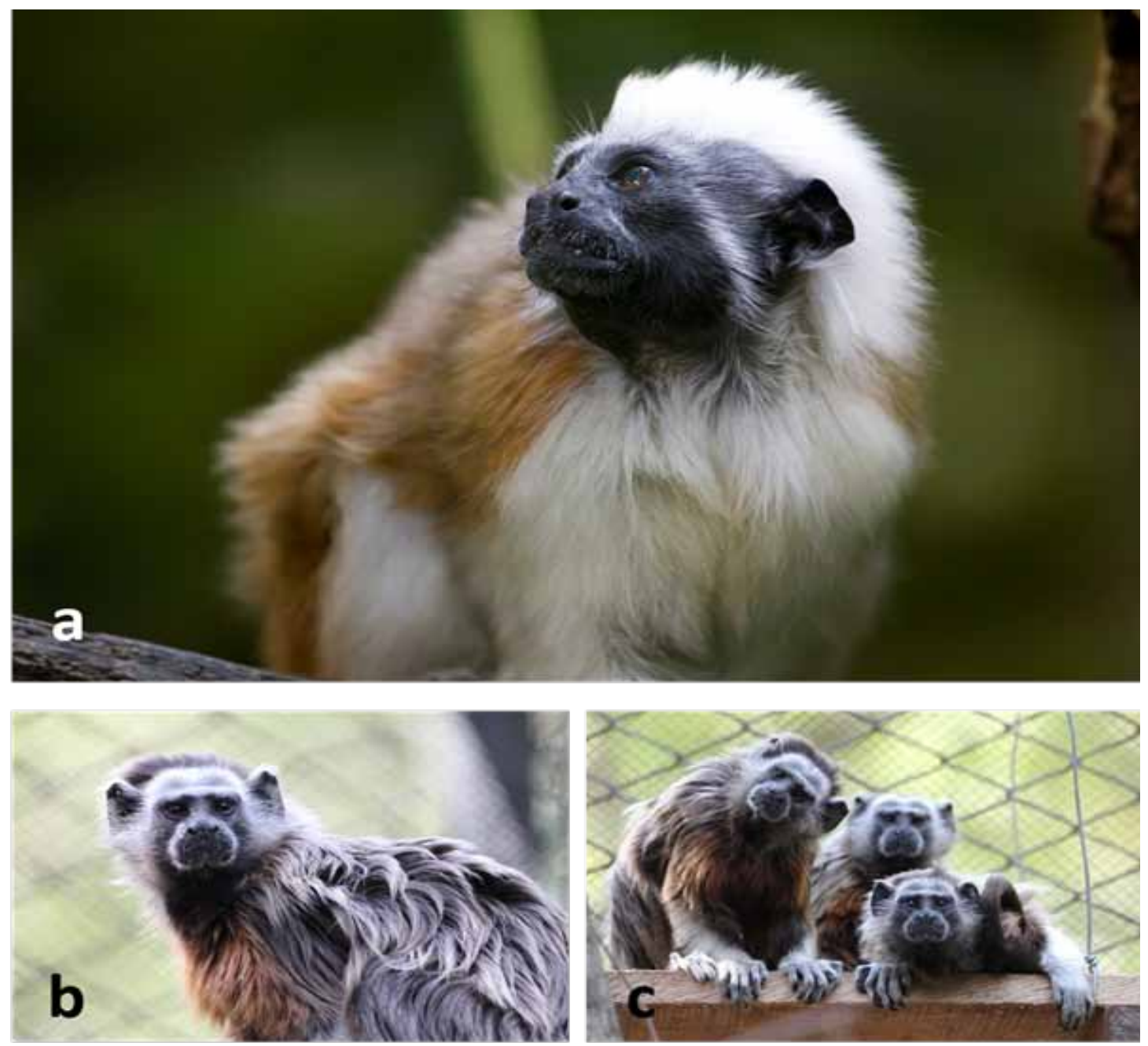

Figure 1. Cotton-top tamarin (Saguinus oedipus, a) and some individuals of the white-footed tamarin group (Saguinus leucopus, b and c) during their transient stay at Cali Zoo, Cali, Colombia. These small Neotropical primate species endemic to Colombia have lost the majority of their original distribution due to intensive colonization and previous unregulated extraction for biomedical research (S. oedipus). Current threats include ongoing forest cover loss, and proposed dam constructions (5). Disease is not currently considered a threat for these species. Photo: Susan Posada@ 2013-2014.

and the local department of natural resources (Autonomous Regional Corporation of Valle - CVC) in addition to the technical, scientific and administrative ethics policies in Law 84 (Colombia National Congress, 1989).

Serology testing. Approximately 200 $\mu \mathrm{L}$ of blood sera was used to conduct a microagglutination test (MAT) with 19 reference strains from the Royal Tropical Institute (Netherlands) at the Leptospirosis Diagnostic Laboratory at Universidad del Valle in Cali, Colombia. The strain pool included $(L$. interrogans) grippotyphosa, (L. santarosai) celledoni, ( $L$. interrogans) pomona, ( $L$. noguchi) australis, ( $L$. interrogans/L. kirshneri) icterohaemorrhagiae, ( $L$. alexanderi) manhao, ( $L$. interrogans) bataviae, (L. borgpetersenii) sejroe, ( $L$. noguchii) louisiana, ( $L$. borgpetersenii) recursos (Corporación Autónoma Regional del Valle - CVC), adicionalmente a las políticas éticas técnicas, científicas y administrativas de la Ley 84 (Congreso Nacional de Colombia, 1989).

Prueba de Serología. Se utilizaron aproximadamente $200 \mu \mathrm{L}$ de suero sanguíneo para realizar una prueba de microaglutinación (MAT) con 19 cepas de referencia del Royal Tropical Institute (Holanda) y el Laboratorio Diagnóstico de Leptospirosis de la Universidad del Valle en Cali, Colombia. El pool de cepas incluyó (L. interrogans) grippotyphosa, (L. santarosai) celledoni, ( $L$. interrogans) pomona, ( $L$. noguchi) australis, ( $L$. interrogans/L. kirshneri) icterohaemorrhagiae, $(L$. alexanderi) manhao, ( $L$. interrogans) bataviae, $(L$. borgpetersenii) sejroe, (L. noguchii) louisiana, ( $L$. 
javanica, ( $L$. santarosai) shermani, ( $L$. interrogans) djasmin, (L. santarosai) mini, ( $L$. interrogans) pyrogenes, $(L$. fainei) hurtsbridge, ( $L$. borgpettersenii) ballum, ( $L$. weillii) ranarum, ( $L$. interrogans) canicola, and ( $L$. biflexa) seramanga. Strains are subcultured weekly in EllinghausenMcCullough-Johnson-Harris medium at $30^{\circ} \mathrm{C}$. Strains are typically diluted $1: 2$ with buffer until a density of 6-8 x 108 spirochetes/ $\mathrm{mL}$ is evidenced. Each of the samples were stored at $-20^{\circ} \mathrm{C}$ and thawed via refrigeration. Aliquots of $50 \mu \mathrm{L}$ in buffer (1X PBS, pH 7.2) were placed in the first row of a microplaque as control antigen. Each blood sera sample was placed along the remaining rows and mixed with the reference strain (antigen) arranged in columns. Microplaques were covered and incubated at $30^{\circ} \mathrm{C}$ for 2 hours. To evidence microagglutination, each aliquot was transferred to a glass slide and scanned by dark-field microscopy. Samples displaying a dilution $\geq 1: 100$ in which $75 \%$ of the spirochetes were agglutinated was considered positive; starting and end dilutions were $1: 50$ and $1: 3200$, respectively.

\section{RESULTS}

MAT results for all $S$. leucopus were negative or $<1: 50$. In contrast, samples from the only $S$. oedipus yielded a titer of $\geq 1: 3200$ against $L$. alexanderi serovar manhao. In the same individual, further blood examination revealed an erythrocytosis and hyperproteinemia.

\section{DISCUSSION}

Evidence of hemoconcentration with hyperproteinemia is considered dehydration; an inspecific clinical sign of leptospiral infection. Ketamine $\mathrm{HCl}$ and midazolam have been safely used in wild $S$. leucopus in the past, even at higher doses (7); although how these drugs affect blood cell parameters is not well understood in this species. Thus, it is important to consider that all anesthetic agents have the potential of altering blood parameters, as well as the stress induced by the captivity and handling of a wild animal. Generally, during certain types of anesthesia, erythrocytes and leukocytes decrease due to depression of the cardiovascular system (8). Other exogenous stimuli such as stress may have an opposite effect, in which corticosteroidinduced responses from their endogenous release influence leukocyte counts more commonly than other cell lines; typically represented by lymphopenia and neutrophilia (9). In other primates, reports of anesthesia borgpetersenii) javanica, (L. santarosai) shermani, (L. interrogans) djasmin, ( $L$. santarosai) mini, $(L$. interrogans) pyrogenes, (L. fainei) hurtsbridge, $(L$. borgpettersenii) ballum, ( $L$. weillii) ranarum, $(L$. interrogans) canicola, y ( L. biflexa) seramanga. Las cepas fueron subcultivadas semanalmente en un medio Ellinghausen-McCullough-Johnson-Harris a $30^{\circ} \mathrm{C}$. Las cepas fueron diluidas $1: 2$ con buffer hasta evidenciar una densidad de 6-8 x 108 espiroquetas/ $\mathrm{ml}$. Cada una de las muestras fue almacenada a $-20^{\circ} \mathrm{C}$ y descongelada a través de refrigeración. Se colocaron alícuotas de $50 \mu \mathrm{L}$ en buffer (1xPBS $\mathrm{pH}$ 7.2) en la primera línea de una microplaca como antígeno de control. Cada muestra de suero sanguíneo fue colocada en las filas restantes y mezclada con la cepa de referencia (antígeno) organizada en columnas. Las microplacas fueron cubiertas e incubadas a $30^{\circ} \mathrm{C}$ por 2 horas. Para evidenciar migroaglutinación, cada alícuota fue transferida a una lámina de vidrio y escaneada en un microscopio de campo oscuro. Las muestras que mostraron una dilución $\geq 1: 100$ en la cual el $75 \%$ de las espiroquetas se aglutinó se consideraron positivas; las diluciones de inicio y final fueron de $1: 50$ y $1: 3200$, respectivamente.

\section{RESULTADOS}

Los resultados de la MAT para S. leucopus fueron negativos o $<1: 50$. En contraste, las muestras de la única $S$. oedipus arrojaron una concentración de $\geq 1: 3200$ contra $L$. alexanderi serovar manhao. En el mismo individuo, examenes sanguíneos adicionales revelaron eritrocitosis e hiperproteinemia.

\section{DISCUSIón}

La evidencia de hemoconcentración acompañada por hiperproteinemia se considera deshidratación; un signo clínico inespecíficos de infección por leptospiras. El $\mathrm{HCl}$ Ketamina y midazolam han sido usados de manera segura en $S$. leucopus en el pasado, aún en dosis mayores (7); aunque faltan más estudios que determinen cómo estas drogas afectan los parámetros sanguíneos en estas especies. Por esto, es importante considerar que todos los agentes anestésicos tienen el potencial de alterar los parámetros sanguíneos, así como el estrés inducido por la cautividad y el manejo de un animal silvestre. Generalmente, durante ciertos tipos de anestesia, los eritrocitos y leucocitos disminuyen debido a la depresión del sistema cardiovascular (8). Otros estímulos exógenos tales como el estrés pueden tener el efecto opuesto, en el cual las respuestas inducidas por la liberación endógena de corticoesteroides pueden influenciar los conteos de leucocitos de manera más común que otras líneas de células; se representan típicamente por linfopenia y neutrofilia (9). En otros primates, reportes de anestesia con 
with ketamine document erythrocytosis and leukocytosis due to hemoconcentration (8), which may also explain the hyperproteinemia evidenced in our case report of anesthesia with ketamine. It is also possible that the hemoconcentration observed is due to pressor effects of ketamine, as it has been evidenced in other primates when low doses of dissociative agents are administered (8). The effects of benzodiazepine anesthesia in the blood cells of rats are primarily splenic lymphocytic depletion and low hematocrit due to increased erythrocyte destruction (10), which does not coincide with our blood and serum screening results. Despite the lack of supporting evidence of midazolam altering blood parameters in this report, it is important to consider these in future studies and perhaps compare $\mathrm{CBC}$, biochemistry and serology results from paired blood and sera samples using the same anesthetic agents.

In the past, transmission experiments with Leptospira have elicited fatal disease in $S$. oedipus and S. geoffroyi (11), and more recently in S. labiatus (12), and in other captive callitrichids such as Callithrix kuhlii (13). Minette (3) found a serorreactive $S$. oedipus to serovar ballum (known to circulate in the domestic mouse, Mus spp.) among a group of eight individuals in the U.S. Reports in other marmoset species (Callithrix spp.) have found titers of up to $1: 200$ in asymptomatic animals (14). In 2009, Gonzalez-Astudillo et al (15) tested in Cali Zoo two Leontocebus fuscicollis that were negative or $<1: 50$ with the MAT. However, one Cebus albifrons did test positive and underwent an asymptomatic infection eliciting low titers $(1: 160)$ to serovar australis. Another study conducted in captive primates in Colombia found titers of up to $1: 1600$ in an asymptomatic monkey (16). However, in the same study, six S. oedipus were negative.

It has been established already that nonhuman primates are more likely to acquire leptospiral infection in captivity; nevertheless, it is not known for how long titers remain detectable following a natural infection (3), and this is likely influenced by intraspecific factors or aspects inherent to the pathogen. Leptospira-infected primates can also turn into carriers (16), however this was not demonstrated in this study. Without further testing, these animals should be confined until their renal carrier state has been cleared. It is important that in future studies, when possible, asymptomatic primates with ketamina documentan eritocitrosis y leucocitosis debido a hemoconcentración (8), que también puede explicar la hiperproteinemia evidenciada en nuestro reporte de caso. También es posible que la hemoconcentración observada se deba a efectos presores de la ketamina, como se ha evidenciado en otros primates cuando se administran dosis bajas de agentes disociativos (8). Los efectos de la anestesia con benzodiacepinas en células sanguíneas en ratas son principalmente depleción esplénica linfocítica y disminución de hematocrito debido a un incremento en la destrucción de eritrocitos (10), que no coincide con nuestros resultados en sangre y suero. A pesar de la falta de evidencia que apoye la alteración de parámetros sanguíneos tras la administración de midazolam en este reporte, es importante considerarlos en estudios futuros comparando los resultados de muestras pareadas de cuadros hematicos, bioquímica y serología utilizando los mismos agentes anestésicos.

En el pasado, la transmisión experimental de leptospiras ha desencadenado infecciones fatales en S. oedipus y S. geoffroyi (11), y más recientemente en S. labiatus (12). En cautiverio, se han presentado cuadros fatales en otros calitrícidos en cautiverio como Callithrix kuhlii (13). Minette (3) encontró serorreactividad en $S$. oedipus al serovar ballum (conocido por ser portado por el ratón doméstico, Mus spp.) pertenecientes a un grupo de ocho individuos en EE.UU. Reportes en otras especies de tití (Callithrix spp.) han encontrado títulos de hasta 1:200 en animales asintomáticos (14). En 2009, Gonzalez-Astudillo et al (15) encontró en el Zoológico de Cali dos Leontocebus fuscicollis que fueron negativos o <1:50 con la MAT. Sin embargo, un Cebus albifrons tuvo una infección asintomática con títulos bajos $(1: 160)$ al serovar australis. Otro estudio llevado a cabo en primates en cautiverio en Colombia encontró títulos de hasta 1:1600 en individuos asintomáticos (16). Sin embargo, en el mismo estudio, los seis S.oedipus muestreados resultaron negativos.

Ya ha sido establecido que los primates no humanos tienen mayor posibilidad de adquirir infección leptospiral en cautiverio; sin embargo, no se conoce por cuánto tiempo los títulos permanecen detectables después de una infección natural (3), $y$ esto puede estar influenciado por factores 0 aspectos intraespecíficos inherentes al patógeno. Los primates infectados con Leptospira también se pueden tornar portadores (16), sin embargo esto no se ha demostrado en este estudio. Sin pruebas adicionales, estos animales deben ser confinados hasta que su estado de portador renal haya sido esclarecido. Es bien sabido que varios centros de recepción de fauna silvestre decomisada por la Policía Ambiental en Colombia liberan los animales tras su recepción. Sin pruebas 
high titers are confined until their renal carrier status has been determined. Since some of the institutions receiving confiscated wildlife from the Environmental Police in Colombia are known to release animals back into their habitat, the potential to disseminate pathogens, including Leptospira spp. is a high risk for primate conservation and public health in Colombia, even if there is currently no documentation of a primateto-human transmission or viceversa of the bacterium.

In Colombia, the infrastructure for longterm, large scale monitoring of health in wild animals is virtually inexistent and acquisition of wild animals or samples is usually opportunistic; thus, morbidity and mortality events caused by leptospirosis or any other disease can easily be overlooked. Wild animals are received in Colombia at rehabilitation centers adjunct to regional environmental entities, which determine the fate of the individual (e.g. release, euthanasia, or captivity). Due to financial and logistical constraints, testing for several pathogens is not always feasible in releasable animals. Ideally, establishing collaborations with governmental diagnostic centers in orden to conduct routinely testing with available assays. In regards to leptospirosis, incorporate MAT pools with larger numbers of serovars and serogroups in paired sampling, or other diagnostic tests (e.g. molecular techniques) to detect renal carriers as mandatory procedures in pre-release protocols as they can provide a better understanding of the infectious status of individuals. This can build baseline information that can guide future guidelines to the management of animals destined for reintroduction.

Saguinus sp. are one of the most trafficked genera in Colombia, because of their size and perceived ease of becoming tame. Despite this reality, little attention has been given to the diseases they can acquire in captivity, especially those considered threats for public health and primate conservation. This marmoset was not tested at arrival for anti-leptospiral antibodies; thus, we cannot discern when the infection occurred. However, it is possible that the marmoset got infected during its transportation to a major metropolitan center for sale, and it could have been reinfected again at Cali Zoo, eliciting this strong reaction to a serovar recognized by his immune system, and undergoing an asymptomatic infection for unknown reasons. adicionales, estos individuos tienen el potencial de diseminar patógenos en su hábitat, incluyendo Leptospira spp., lo cual podría ser un alto riesgo para la conservación de primates y la salud pública en Colombia, aun si no hay documentación actual de transmisión de primate a humano o viceversa de la bacteria.

En Colombia, la infraestructura para monitoreo de saludo a largo plazo y de amplia escala en animales silvestres es virtualmente inexistente, ya que la adquisición de muestras provenientes de animales silvestres es usualmente oportunista; por esto, los eventos de morbilidad y mortalidad causados por leptospirosis o cualquier otra enfermedad pueden ser fácilmente pasados por alto. Los animales salvajes son recibidos en Colombia en centros de rehabilitación adjuntos a corporaciones autónomas regionales, que determinan el destino del individuo (ej. liberación, eutanasia o cautiverio). Debido a restricciones financieras y logísticas, hacer las pruebas necesarias para detectar patógenos no es siempre posible en estos animales. Sería ideal establecer convenios con centros de diagnóstico gubernamentales para realizar rutinariamente pruebas que estén disponibles, y con relación a leptospirosis, incorporar al pool de la MAT con mayor número de serovares y serogrupos en muestreos pareados, a la par con otras pruebas diagnósticas (ej. técnicas moleculares) para detectar portadores renales como procedimientos obligatorios en protocolos de pre-liberación ya que pueden ofrecer un mejor entendimiento del estado infeccioso de los individuos. Esto puede construir la información de base para guiar futuros lineamientos sobre el manejo de animales destinados a reintroducción.

Saguinus spp., es uno de los géneros taxonómicos más traficados en Colombia debido a su tamaño y aparente docilidad. A pesar de esta realidad, se ha prestado poca atención a las enfermedades que pueden adquirir en cautiverio, especialmente aquellas consideradas como amenazas a la salud pública y la conservación de primates. Debido a que no se realizaron pruebas al tití a su recepción para encontrar anticuerpos anti-leptospirales, no podemos discernir cuándo ocurrió la infección. Sin embargo, es posible que el tití se infectara durante el transporte desde su habitat hacia el lugar donde fue vendido, pudiéndose infectar de nuevo en el Zoológico de Cali, suscitando una fuerte reacción al serovar que fue reconocido por su sistema inmune pero que indujo una una infección asintomática, por razones desconocidas.

Ocasionalmente, infecciones simultáneas con otros serogrupos, también conocidas como "reacciones paradójicas" pueden interferir al determinar el serovar infectante (3). Adicionalmente, puede existir cierta variabilidad relacionada con la especie en la 
Occasionally, simultaneous infections with other serogroups or paradoxical reactions may interfere with determining the infecting serovar (3). In addition, there may be a species-related variability in humoral response to leptospiral infection (e.g. titer duration) (3). Although hemoconcentration of a sample may overestimate hyperimmunoglobulinemia, a titer $\geq 1: 3200$ with the MAT in combination with no visible clinical signs could suggest an undergoing infection. Another possible explanation is that continuous exposure to infection throughout life can result in an age-dependent increment in seropositivity to Leptospira (16). Past infections in nonhuman primates are typically associated with low titers for prolonged periods in asymptomatic individuals (17). Although the MAT precludes the establishment of the time of the infection and it is not considered a serovar-specific test because of its known cross-reactivity within serogroups (18), cases in which a single sample has elevated titers is considered diagnostic (1), and can indicate the presumptive infecting serovar (18). Although some reports exist in the literature about leptospirosis in Saguinus marmosets, to our knowledge, this is the first documentation regarding such high titers in an asymptomatic individual. It is likely that Leptospira transmission is more common that it is currently known in Colombia, as it has been demonstrated in a few seroprevalence studies in wild mammals (19) and zoological collections $(15,16)$. In contrast, there are few citable documents about Leptospira prevalence in wildlife or zoo mammals. All marmosets were kept under observation for possible onset of symptoms and their clinical status will dictate their fate. Clinical staff and caretakers exercise biosafety measures to avoid pathogen transmission to themselves and other captive fauna.

Clinical signs associated with leptospirosis in mammals are usually non-pathognomonic (1), with reports in non-human primates documenting weight loss, diarrhea, dehydration, anorexia, jaundice, and anemia (13). The $S$. oedipus female in this report only elicited dehydration, perhaps due to previous exposure to the bacterium, or low virulence of the infecting serovar. The MAT detects immunoglobulin $M$ (IgM), usually produced in the acute phase of the infection; the onset of clinical signs usually coincides with its decrease in plasma.

Cali Zoo is one of the few zoological institutions in Colombia actively investigating respuesta humoral de la infección por leptospiras (ej. duración de la concentración) (3). Aunque la hemoconcentración de una muestra puede inducir erróneamente una hiperinmunoglobulinemia, una concentración de $\geq 1: 3200$ con la MAT en combinación con ausencia de signos clínicos podría sugerir una infección en curso. Otra posible explicación es que la exposición repetida a la infección por Leptospira puede resultar en un incremento dependiente de la edad que se refleja en aumento de la serorreactividad reflejada en títulos (16). Las infecciones anteriores en primates no humanos se asocian comúnmente con títulos bajos por periodos prolongados en individuos asintomáticos (17). Aunque el MAT excluye establecer el tiempo de infección y no se considera una prueba serovar-especifica debido a un reacción cruzada conocida con serogrupos (18), casos en los que una sola muestra tiene concentraciones elevadas se consideran diagnósticos (1), y pueden indicar un serovar infectante presuntivo (18). Aunque existen algunos reportes en la literatura sobre leptospirosis en titís Saguinus, a nuestro conocimiento, esta es el primer reporte con relación a títulos altos en individuos asintomáticos. Es posible que la transmisión de Leptospira en animales silvestres sea más común de lo que se conoce en Colombia, como se ha demostrado en varios estudios de seroprevalencia en mamíferos silvestres (19) y en colecciones de zoológicos $(15,16)$. En contraste, son pocos los documentos citables son sobre la prevalencia de Leptospira en vida silvestre o mamíferos de zoológico. Todos los titís se mantuvieron bajo observación para la posible aparición de síntomas y su estatus clínico dictará su destino. El personal clínico y los cuidadores ejercen medidas de bioseguridad para prevenir transmisión de patógenos a ellos mismos u otra fauna cautiva.

Los signos clínicos asociados con leptospirosis en primates no humanos son usualmente no patognomónicos (1), con reportes que incluyen la pérdida de peso, diarrea, deshidratación, anorexia, ictericia y anemia (13). La infección en la hembra de $S$. oedipus en este reporte solo suscitó deshidratación, posiblemente debido a exposición previa a la bacteria, o baja virulencia del serovar infeccioso. EI MAT detecta inmunoglobulina M (IgM), usualmente producida en la fase aguda de la infección; la aparición de signos clínicos usualmente coincide con la disminución de IgM en plasma.

El Zoológico de Cali es una de las pocas instituciones en Colombia que investiga activamente (14) y diagnostica infección por leptospiras, entre 
(14) and diagnosing leptospiral infection, amongst other disease-causing etiologies, within their collection. It is important to encourage other zoological institutions and wildlife rehabilitation centers to incorporate screening for Leptospira spp. as part of their test pool for incoming animals. This would improve the understanding of the dynamics of Leptospira in non-domestic animal species, and could lay the foundation for the improvement of the current management practices for confiscated wildlife.

\section{Acknowledgements}

This study was financially supported by the Zoological Foundation of Cali and the Leptospirosis Diagnostic Laboratory at Universidad del Valle, both in Cali, Colombia. The authors would like to thank the zoo keepers and veterinary staff at Cali Zoo, and to Mrs. Leonor Oviedo for her help with blood sera processing. otras etiologías que causan enfermedades, en su colección. Es importante animar a otras instituciones zoológicas y centros de rehabilitación de vida silvestre a incorporar la detección de Leptospira spp. como parte de su grupo de pruebas para animales entrantes. Esto mejoraría el conocimiento de la dinámica de Leptospira en especies animales no domésticas y podría crear la base para mejorar las prácticas actuales de manejo de vida silvestre decomisada.

\section{Agradecimientos}

Este estudio fue apoyado financieramente por la Fundación Zoológica de Cali y el Laboratorio Diagnóstico de Leptospirosis de la Universidad del Valle, ambos en Cali, Colombia. Los autores quisieran agradecer a los cuidadores del zoológico y el personal veterinario en el Zoológico de Cali, y a la Sra. Leonor Oviedo por su ayuda con el procesamiento del suero de la sangre.

\section{REFERENCES}

1. Adler B, de la Pena-Moctezuma A. Leptospira and leptospirosis. Vet Microbiol 2010; 140(3-4):287-96.

2. Pavlin BI, Scholoegel LM, Daszak P. Risk of importing zoonotic diseases through wildlife trade, United States. Emerg Infect Dis 2009; 15(11):1721-26.

3. Minette HP. 1966. Leptospirosis in primates other than man. Am J Trop Med Hyg $1966 ; 15(2): 190-198$.

4. Ulloa A, Baptiste-Ballera LG. Editores. Rostros culturales de la fauna. $1^{a}$ edición. Bogotá: Instituto de Investigación de Recursos Biológicos Alexander Von Humboldt and Instituto Colombiano de Antropologia e Historia; 2002.

5. International Union for the Conservation of Nature - IUCN. 2014 [July 20 2014]; available in: http://www.iucn.org.

6. Instituto de Hidrologia, Metereologia y Estudios Ambientales - IDEAM. 2014 [August 10 2014]; available in: http://bart. ideam.gov.co/cliciu/cali/tabla.htm
7. Savage A, Giraldo LH, Blumer ES, Soto LH, Burger W, Snowdon CT. Field techniques for monitoring cotton-top tamarings (Saguinus oedipus oedipus) in Colombia. Am J Primatol 1993; 31(3):189-196.

8. Wall HS, Worthman C, Else G. Effects of ketamine anesthesia, stress and repeated bleeding on the haematology of vervet monkeys. Lab Anim 1985; 19(2):138-144.

9. Dhabhar FS, Miller AH, McEwen BS, Spencer RL. Effects of stress on immune cell distribution - dynamics and hormonal mechanisms. J Immunol 1995; 154(10):5511-5527.

10. Elmesallamy GE, Abass MA, Ahmed-Refat NAG, Atta AH. Differential effects of alprazolam and clonazepam on the immune system and blood vessels of non-stressed and stressed adult male albino rats. Interdiscip Toxicol 2011; 4(3):132-143.

11. Noguchi H. Etiology of yellow fever. II. Transmission experiments on yellow fever. J Exp Med 1919; 29(6):565-84. 
12. Reid HA, Herron $A J$, Hines ME $2^{\text {nd }}$, Orchard $\mathrm{EA}$, Altman NH. Leptospirosis in a whitelipped tamarin (Saguinus labiatus). Lab Anim Sci 1993; 43(3):258-9.

13. Baitchman EJ, Calle PP, James SB, Linn MJ, Raphael BL. Leptospirosis in Wied's marmosets (Callithrix kuhlii). J Zoo Wild Med 2006; 37(2):182-5.

14. Pinna $M H$, Martins $G$, Pinheiro ACO, Almeida DS, Oria AP, Lilenbaum W. Detection of antiLeptospira antibodies in captive nonhuman primates from Salvador, Brazil. Am J Primatol 2012; 74(1):8-11.

15. Gonzalez-Astudillo V, Wehdeking D, Pena-Stadlin JE, Arias-Bernal L, LomboRodriguez DA, Astudillo-Hernandez M. Comparative seroprevalence of Leptospira interrogans in Colombian mammals along a climatic gradient. J Zoo Wild Med 2012; 43(4): 768-775.
16. Romero M, Astudillo M, Sanchez J, Gonzalez L, Varela N. Titulos de anticuerpos contra Leptospira sp., en primates del zoológico Matecana, Pereira, Colombia. Rev MVZ Cordoba 2012; 17(3):3224-30.

17. Johnson MAS, Smith $H$, Joseph $P$, Gilman $R H$, Bautista CP, Campos KJ, et al. Enviromental exposure and leptospirosis, Peru. Emerg Infect Dis 2004; 10(6):1016-22

18. Levett PN. Usefulness of serologic analysis as a predictor of the infecting serovar in patients with severe leptospirosis. Clin Infect Dis 2003; 36(4):447-52.

19. Wells EA, D'Alessandro A, Morales GA, Angel D. Mammalian wildlife diseases as hazards to man and livestock in an area of the Llanos Orientales of Colombia. J Wild Dis 1981; 17(10):153-62. 